\title{
Contrast Experiment on Advanced Treatment of Pharmaceutical and Paper-making Wastewater through Cinder Fenton-like Process
}

\author{
Jia Xiaofeng ${ }^{1,2}$, Chen Xiaoyu², and Mai Wenning ${ }^{3}$ \\ ${ }^{1}$ Luohe Yinge Industrial Group Co., Ltd,462003, Luohe, Henan, China \\ ${ }^{2}$ Zhengzhou University of Aeronautics,450000, Zhengzhou, China \\ ${ }^{3}$ Zhengzhou University of Aeronautics,450000, Zhengzhou, China
}

\begin{abstract}
The Fenton-like process of catalyzing $\mathrm{H}_{2} \mathrm{O}_{2}$ with $\mathrm{Fe}^{2+}$ and cinder is adopted to subject pharmaceutical and paper-making wastewater to advanced treatment. The influence of each factor is determined using orthogonal experiment and single factor test. The optimal combination of influencing factors is $0.3 \mathrm{mmol} \cdot \mathrm{L}^{-1}$ of $\mathrm{FeSO}_{4} \cdot 7 \mathrm{H}_{2} \mathrm{O},\left[\mathrm{H}_{2} \mathrm{O}_{2}\right]:\left[\mathrm{Fe}^{2+}\right]=8: 1$ and $10 \mathrm{~g} \cdot \mathrm{L}^{-1}$ of pyrites cinder. The reaction time in pharmaceutical wastewater and paper-making wastewater is $30 \mathrm{~min}$ and $60 \mathrm{~min}$ respectively, testifying to the fact that the reaction in pharmaceutical wastewater is faster than that in paper-making wastewater and the lower utilization rate of cinder in pharmaceutical wastewater. Under the optimal reaction condition, the COD removal rate of these two kinds of wastewater can reach as high as $65 \%$ and $72 \%$. Characterized by simple operation and requiring less reagent dosage, this method does not have to regulate the $\mathrm{pH}$ of flooding water and allows the repeated usage of cinder.
\end{abstract}

\section{Introduction}

Fenton reaction ${ }^{[1]}$ refers to the production of hydroxyl radical with strong oxidizing property by catalyzing $\mathrm{H}_{2} \mathrm{O}_{2}$ with $\mathrm{Fe}^{2+}$ that is used to oxidize and degrade contaminants. Despite its strong oxidizability, Fenton's reagent first requires the addition of acid and then alkali to adjust the $\mathrm{pH}$ to neutral. The complicated operation and frequent adjustment of $\mathrm{pH}$ will increase the operational costs and investment costs of infrastructure equipment ${ }^{[2]}$.

With $\mathrm{Fe}$ content of $30 \sim 55 \%$ and $\mathrm{Si}, \mathrm{Ca}, \mathrm{Mg}, \mathrm{Mn}, \mathrm{Cu}$ and $\mathrm{Zn}$, pyrites cinder refers to the waste residue from the production of sulfuric acid with pyrite ${ }^{[3]}$. Recent researches show that the pyrites cinder is highly active in catalyzing ${ }^{[4-5]}$ the oxidation of $\mathrm{H}_{2} \mathrm{O}_{2}$ and effective in forming the new Fenton-like reaction with surface catalysis as the mechanism, which testifies to good treatment of Acid Red B, phenol and many other actual industrial wastewater.

The wastewater from a pharmaceutical company and a paper-making company in Henan are all subjected to the traditional anaerobic and aerobic treatment. The pharmaceutical wastewater, with complicated components, high concentration, high toxicity, dark color and strong smell, hardly degradable substances and inhibitory drugs ${ }^{[6-7]}$, is difficult to be treated. With the implementation of Discharge Standard of Water Pollutants for Pharmaceutical Industry Fermentation Products Category (GB21903-2008), the single secondary biological treatment cannot satisfy the requirements. Characterized by high chromaticity and poor biodegradability, the paper-making wastewater usually contains chlorinated aromatic compounds ${ }^{[10]}$ as a result of the usage of decolorizer, thus bringing harm to environment and human health ${ }^{[11]}$. For these reasons, it is a must to subject both the pharmaceutical and papermaking wastewater to advanced treatment. Under the condition of not regulating $\mathrm{pH}$, the experiment of treating the secondary effluent from pharmaceutical and paper-making wastewater with $\mathrm{H}_{2} \mathrm{O}_{2}$ under the catalysis of pyrites cinder shows that there is no obvious decrease of COD. Therefore, the author intends to adopt the Fenton-like process of catalyzing $\mathrm{H}_{2} \mathrm{O}_{2}$ with pyrites cinder and $\mathrm{Fe}^{2+}$ to study the feasibility of the advanced treatment of pharmaceutical and paper-making wastewater.

\section{Materials and methods}

\subsection{Test water quality}

The water is from the aerobic treatment secondary effluent of a pharmaceutical and a paper-making company in Henan, whose quality is presented in Table 1.

Table 1. Water quality of secondary effluent

\begin{tabular}{lcccc}
\hline Item & $\begin{array}{c}\rho_{(\mathrm{CODcr}) /} \\
\left(\mathrm{mg} \cdot \mathrm{L}^{-1}\right)\end{array}$ & $\begin{array}{c}\rho_{(\mathrm{BOD} 5) /} \\
\left(\mathrm{mg} \cdot \mathrm{L}^{-1}\right)\end{array}$ & $\begin{array}{c}\rho_{(\mathrm{SS}) /} \\
\left(\mathrm{mg} \cdot \mathrm{L}^{-1}\right)\end{array}$ & $\mathrm{pH}$ \\
\hline
\end{tabular}

\footnotetext{
* Corresponding author: 191826850@qq.com
} 


\begin{tabular}{ccccc}
\hline $\begin{array}{c}\text { Pharmaceuti } \\
\text { cal } \\
\text { Wastewater }\end{array}$ & $100 \sim 150$ & $12 \sim 16$ & $40 \sim 60$ & $7.5 \sim 8.0$ \\
$\begin{array}{c}\text { Paper- } \\
\text { making } \\
\text { Wastewater }\end{array}$ & $240 \sim 270$ & $20 \sim 40$ & $30 \sim 50$ & $7.5 \sim 8.5$ \\
\hline
\end{tabular}

For easier comparison, the paper-making wastewater is diluted with equal amount of water during experiment.

\subsection{Experimental method}

$1000 \mathrm{~mL}$ wastewater, together with pyrites cinder and a certain amount of $\mathrm{FeSO}_{4} \cdot 7 \mathrm{H}_{2} \mathrm{O}$ and $\mathrm{H}_{2} \mathrm{O}_{2}(30 \%)$ is added to the $1000 \mathrm{~mL}$ beaker for reaction. After $20 \mathrm{~min}$ of aeration and $30 \mathrm{~min}$ of static settlement, the supernate is taken to test its COD.

\subsection{Analysis item and methods}

pH: glass electrode method; COD: potassium dichromate method; BOD: standard dilution method; SS: $103 \sim 105^{\circ} \mathrm{C}$ oven drying and weighing method ${ }^{[12]}$.

\section{Results and analysis}

\subsection{Orthogonal test}

The four controllable parameters, namely, amount of pyrites cinder, $\left[\mathrm{H}_{2} \mathrm{O}_{2}\right]:\left[\mathrm{Fe}^{2+}\right]$, dosage of $\mathrm{FeSO}_{4} \cdot 7 \mathrm{H}_{2} \mathrm{O}$ and reaction time, are used as the influencing factor of orthogonal test. Three representative levels of each influencing factor is chosen and presented in Table 2.

Table 2. Influencing factor and level of orthogonal test

\begin{tabular}{ccccc}
\hline \multirow{2}{*}{$\begin{array}{c}\text { Leve } \\
1\end{array}$} & \multicolumn{4}{c}{ Influencing Factor } \\
\cline { 2 - 5 } & $\begin{array}{c}\text { Cinder } \\
\text { amount }(\mathrm{A}) \\
\left(\mathrm{g} \cdot \mathrm{L}^{-1}\right)\end{array}$ & $\begin{array}{c}(\mathrm{B}) \\
{\left[\mathrm{H}_{2} \mathrm{O}_{2}\right]:\left[\mathrm{Fe}^{2+}\right]}\end{array}$ & $\begin{array}{c}\mathrm{n}\left(\mathrm{Fe}^{2+}\right) \\
/(\mathrm{C}) \\
\left(\mathrm{mmol} \cdot \mathrm{L}^{-1}\right)\end{array}$ & $\begin{array}{c}\text { Reaction } \\
\text { Time } /(\mathrm{D}) \\
(\mathrm{min})\end{array}$ \\
\hline 1 & 5 & $4: 1$ & 0.1 & 20 \\
2 & 15 & $8: 1$ & 0.2 & 60 \\
3 & 30 & $12: 1$ & 0.3 & 120 \\
\hline
\end{tabular}

According to the determined factor, level and the L9 $\left(3^{4}\right)$ orthogonal table, the experiment is carried out with COD removal rate as the standard of evaluation, as shown in Table 3. The size of influencing factor determined through range is shown in Table 4.

Table 3. Orthogonal text results

\begin{tabular}{ccccccc}
\hline $\begin{array}{c}\text { Test } \\
\text { No. }\end{array}$ & A & B & C & D & $\begin{array}{c}\text { Removal Rate } \\
\text { of COD in } \\
\text { Pharmaceutica } \\
\text { 1 Wastewater\% }\end{array}$ & $\begin{array}{c}\text { Removal Rate } \\
\text { of COD in } \\
\text { Paper-making } \\
\text { Wastewater\% }\end{array}$ \\
\hline 1 & 5 & $4: 1$ & 0.1 & 20 & 18.6 & 25.7 \\
2 & 5 & $8: 1$ & 0.2 & 60 & 57.3 & 67.5 \\
3 & 5 & $12: 1$ & 0.3 & 120 & 61.1 & 70.2 \\
4 & 15 & $4: 1$ & 0.2 & 120 & 39.2 & 43.7 \\
5 & 15 & $8: 1$ & 0.3 & 20 & 64.7 & 68.6 \\
6 & 15 & $12: 1$ & 0.1 & 60 & 42.6 & 54.7 \\
7 & 30 & $4: 1$ & 0.3 & 60 & 48.3 & 44.3 \\
8 & 30 & $8: 1$ & 0.1 & 120 & 41.8 & 48.7 \\
9 & 30 & $12: 1$ & 0.2 & 20 & 55.3 & 63.5 \\
\hline
\end{tabular}

It is shown in Table 3 and 4 that the influence of each influencing factor of pharmaceutical wastewater in descending order is $\mathrm{C}>\mathrm{B}>\mathrm{D}>\mathrm{A}$; the optimal combination is $\mathrm{A}_{2} \mathrm{~B}_{2} \mathrm{C}_{3} \mathrm{D}_{1}$, which means the dosage of pyrites cinder of $15 \mathrm{~g} \cdot \mathrm{L}^{-1}$, dosage of $\mathrm{FeSO}_{4} \cdot 7 \mathrm{H}_{2} \mathrm{O}$ of $0.3 \mathrm{mmol} \cdot \mathrm{L}^{-1}$, $\left[\mathrm{H}_{2} \mathrm{O}_{2}\right]:\left[\mathrm{Fe}^{2+}\right]$ (molar ratio) of $8: 1$ and reaction time of $20 \mathrm{~min}$. The influence of each influencing factor of pharmaceutical wastewater in descending order is $\mathrm{B}>\mathrm{C}>\mathrm{A}>\mathrm{D}$. The optimal combination is $\mathrm{A}_{1} \mathrm{~B}_{3} \mathrm{C}_{3} \mathrm{D}_{3}$, which means the dosage of pyrites cinder of $5 \mathrm{~g} \cdot \mathrm{L}^{-1}$, dosage of $\mathrm{FeSO}_{4} \cdot 7 \mathrm{H}_{2} \mathrm{O}$ of $0.3 \mathrm{mmol} \cdot \mathrm{L}^{-1},\left[\mathrm{H}_{2} \mathrm{O}_{2}\right]:\left[\mathrm{Fe}^{2+}\right]$ (molar ratio) of $12: 1$ and reaction time of $120 \mathrm{~min}$. It shows that the degrading effect in pharmaceutical wastewater under the catalysis of $\mathrm{H}_{2} \mathrm{O}_{2}$ with cinder and $\mathrm{Fe}^{2+}$ is worse than that in paper-making wastewater; however, it takes longer time to treat the paper-making wastewater because cinder can obviously adsorb the chromaticity of paper-making wastewater. However, complete degradation is very slow.

Table 4. Range Analysis(a)

\begin{tabular}{ccccc}
\hline Analysis & \multicolumn{4}{c}{ Pharmaceutical Wastewater } \\
\cline { 2 - 5 } Item & $\mathrm{A}$ & $\mathrm{B}$ & $\mathrm{C}$ & $\mathrm{D}$ \\
\hline K1 & 45.67 & 35.37 & 34.33 & 46.2 \\
K2 & 48.83 & 54.6 & 50.6 & 49.4 \\
K3 & 48.47 & 53 & 58.03 & 49.53 \\
Range R & 3.16 & 19.23 & 23.7 & 3.33 \\
\hline
\end{tabular}

Table 4. Range Analysis(b)

\begin{tabular}{c|cccc}
\hline \multirow{2}{*}{$\begin{array}{c}\text { Analysis } \\
\text { Item }\end{array}$} & \multicolumn{4}{|c}{ Paper-making Wastewater } \\
\cline { 2 - 5 } K1 & A & B & C & D \\
\hline K2 & 55.67 & 37.9 & 42.03 & 52.6 \\
K3 & 52.17 & 61.8 & 58.23 & 54.5 \\
Range R & 3.5 & 23.9 & 19 & 54.2 \\
\hline
\end{tabular}

\subsection{Single factor analysis}

The single factor analysis is carried out by controlling the best level determined by orthogonal test.

\subsubsection{Influence of molar ratio of $\left[\mathrm{H}_{2} \mathrm{O}_{2}\right]:\left[\mathrm{Fe}^{2+}\right]$}

To compare the treatment effect in the two different wastewater under the same condition, $10 \mathrm{~g}$ pyrites cinder and $0.3 \mathrm{mmol} \mathrm{FeSO}_{4} \cdot 7 \mathrm{H}_{2} \mathrm{O}$ are added for $60 \mathrm{~min}$ of reaction in order to study the influence of different $\mathrm{H}_{2} \mathrm{O}_{2}$ dosage on the removal rate of COD in these two different wastewater. The experimental results are shown in Fig. 1.

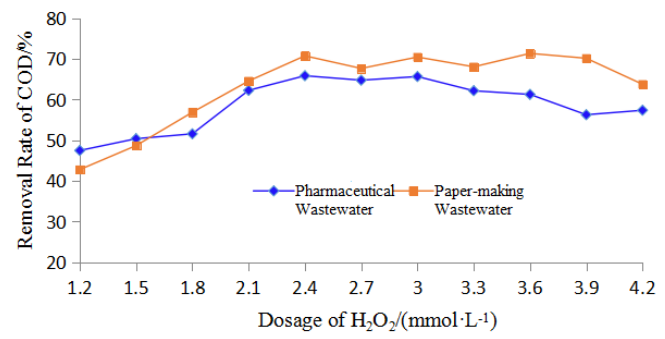

Fig. 1 The influence of $\mathrm{H}_{2} \mathrm{O}_{2}$ dosage on COD removal effect 
Fig. 1 shows that along with the increasing dosage of $\mathrm{H}_{2} \mathrm{O}_{2}$, the removal rate of $\mathrm{COD}$ in pharmaceutical wastewater first increases significantly and then slowly, resulting in the decrease in the removal rate of COD. At lower dosage of $\mathrm{H}_{2} \mathrm{O}_{2}$, the production rate of $\mathrm{OH} \cdot$ along with the increase in the initial concentration, thus significantly increasing the removal rate of COD. At higher dosage of $\mathrm{H}_{2} \mathrm{O}_{2}, \mathrm{OH} \cdot$ will be captured by $\mathrm{H}_{2} \mathrm{O}_{2}$ and $\mathrm{Fe}^{2+}$ as it is produced at very fast rate. The ineffective decomposition of $\mathrm{H}_{2} \mathrm{O}_{2}$ is accelerated with $\mathrm{Fe}^{2+}$ oxidized into $\mathrm{Fe}^{3+}$, which impedes catalysis and gives rise to the unobvious removal effect of COD. With excessive dosage of $\mathrm{H}_{2} \mathrm{O}_{2}, \mathrm{Fe}^{2+}$ will soon be oxidized into $\mathrm{Fe}^{3+}$ at the beginning of reaction. The excessive $\mathrm{H}_{2} \mathrm{O}_{2}$ will also soon be broken into $\mathrm{H} 2 \mathrm{O}$ and $\mathrm{O}_{2}$ and compete with organic matters for $\mathrm{OH} \cdot$ and other free radicals, thus reducing the removal rate of COD. However, the COD removal rate in paper-making wastewater at the later stage decreases insignificantly because the cinder, with good adsorption effect, can thoroughly utilize the iron in the iron in the cinder. An overall consideration of the treatment requirements of wastewater and the important impact of $\mathrm{H}_{2} \mathrm{O}_{2}$ dosage on operation costs shows that $2.4 \mathrm{mmol}_{2} \mathrm{O}_{2}$ can apply to these two wastewater; in other words, the molar ratio of $\left[\mathrm{H}_{2} \mathrm{O}_{2}\right]:\left[\mathrm{Fe}^{2+}\right]$ should be $8: 1$.

\subsubsection{The influence of the dosage of $\mathrm{FeSO}_{4} \cdot 7 \mathrm{H}_{2} \mathrm{O}$}

Under the condition of dosage of cinder of $10 \mathrm{~g}$, $\left[\mathrm{H}_{2} \mathrm{O}_{2}\right]:\left[\mathrm{Fe}^{2+}\right]$ of $8: 1$ and reaction time of $60 \mathrm{~min}$, the dosage of $\mathrm{FeSO}_{4} \cdot 7 \mathrm{H}_{2} \mathrm{O}$ is adjusted. The influence of the dosage of $\mathrm{FeSO}_{4} \cdot 7 \mathrm{H}_{2} \mathrm{O}$ on $\mathrm{COD}$ removal rate is shown in Fig. 2.

Fig. 2 shows that COD removal rate rises along with the increase of $\mathrm{Fe}^{2+}$ dosage. $\mathrm{Fe}^{2+}$ is the essential condition for the production of hydroxyl radical. Under the catalysis of $\mathrm{Fe}^{2+}$, the following reactions will take place $^{[13-14]}$ :

$$
\begin{aligned}
& \mathrm{Fe}^{2+}+\mathrm{H}_{2} \mathrm{O}_{2} \rightarrow \mathrm{OH}^{-+} \cdot \mathrm{OH}+\mathrm{Fe}^{3+} \\
& \mathrm{Fe}^{3+}+\mathrm{H}_{2} \mathrm{O}_{2} \rightarrow \mathrm{Fe}^{2+}+\mathrm{H}^{+}+\cdot \mathrm{O}_{2} \mathrm{H}
\end{aligned}
$$

$$
\mathrm{RH}+\cdot \mathrm{OH} \rightarrow \mathrm{R} \cdot+\mathrm{H}_{2} \mathrm{O}
$$$$
\mathrm{R} \cdot+\mathrm{H}_{2} \mathrm{O}_{2} \rightarrow \mathrm{ROH}+\cdot \mathrm{OH}
$$$$
\mathrm{Fe}^{2+}+\cdot \mathrm{OH} \rightarrow \mathrm{OH}^{-}+\mathrm{Fe}^{3+}
$$

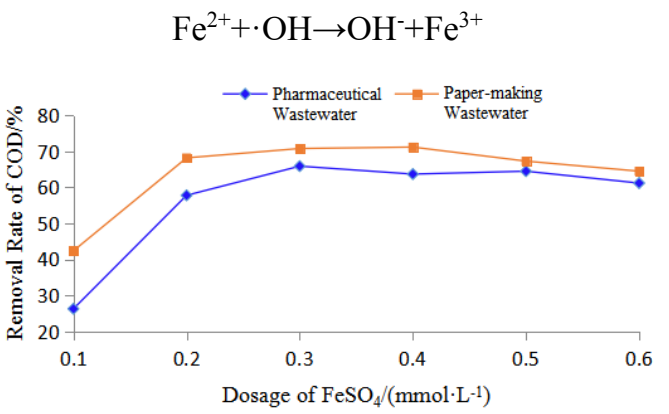

Fig. 2 The influence of $\mathrm{FeSO}_{4}$ dosage on COD removal effect

Higher $\left[\mathrm{Fe}^{2+}\right]$ content will promote the reaction in equation (1) and the high production rate of hydroxyl radicals. After the reaction, the $\mathrm{Fe}^{3+}$ produced is possessed of flocculation, which can remove some of
COD after precipitation and filtration. However, the too high dosage of $\mathrm{Fe}^{2+}$ will also promote the reaction in equation (5) without significantly increasing the removal of COD. As a result, there will also be an increase in the dosage expense and sludge quantity, which will cause secondary pollution. For this reason, the dosage of $\mathrm{FeSO}_{4} \cdot 7 \mathrm{H}_{2} \mathrm{O}$ is determined as $0.3 \mathrm{mmol} \cdot \mathrm{L}^{-1}$.

\subsubsection{The influence of dosage of pyrites cinder}

Under the condition of the dosage of $\mathrm{FeSO}_{4} \cdot 7 \mathrm{H}_{2} \mathrm{O}$ of $0.3 \mathrm{mmol},\left[\mathrm{H}_{2} \mathrm{O}_{2}\right]:\left[\mathrm{Fe}^{2+}\right]$ of $8: 1$ and reaction time of $60 \mathrm{~min}$, the dosage of pyrites cinder is regulated, whose impact on COD removal rate is shown in Fig. 3.

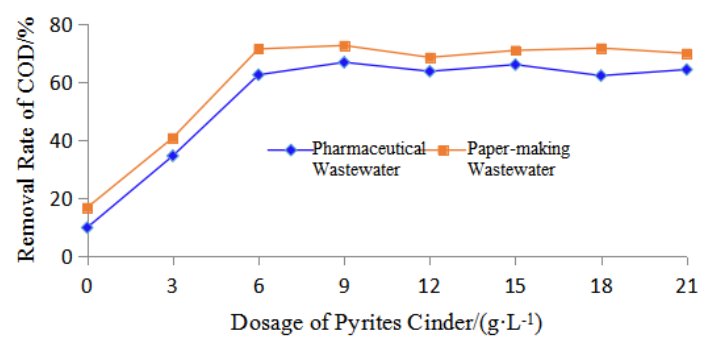

Fig. 3 The influence of dosage of pyrites cinder on COD removal effect

Fig. 3 shows that at lower content of cinder, the COD removal rate rises along with the increase in cinder dosage. After the dosage reaches a certain amount, there is a limited increase in COD removal rate. However, due to its large volume in the reactor and large pressure drop, the power expenses increase. Comparison shows that the optimal dosage of cinder in these two different wastewater is determined as $10 \mathrm{~g} \cdot \mathrm{L}^{-1}$.

\subsubsection{The influence of reaction time}

Under the condition of the dosage of $\mathrm{FeSO}_{4} \cdot 7 \mathrm{H}_{2} \mathrm{O}$ of $0.3 \mathrm{mmol}, 10 \mathrm{~g}$ pyrites cinder and $\left[\mathrm{H}_{2} \mathrm{O}_{2}\right]:\left[\mathrm{Fe}^{2+}\right]$ of $8: 1$, the influence of different reaction time on COD removal effect is investigated with experimental results shown in Fig. 4.

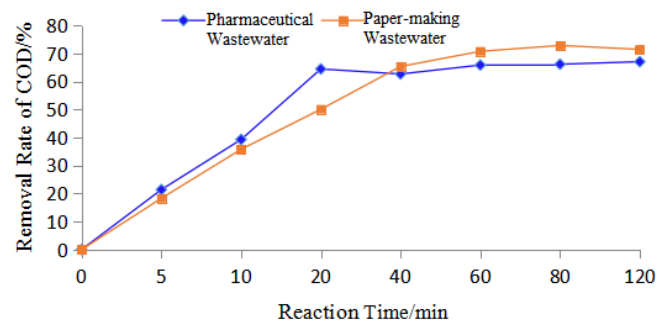

Fig. 4 The influence of reaction time on COD removal effect

It is presented in Fig. 4 that the pharmaceutical wastewater reacts faster than the paper-making wastewater. The COD removal rate basically reaches the highest after 20min in pharmaceutical wastewater and $60 \mathrm{~min}$ in paper-making wastewater. As the reaction time prolongs, there is no obvious change in removal rate because at the beginning of the reaction, the large amount of $\mathrm{H}_{2} \mathrm{O}_{2}$ reacts with $\mathrm{Fe}^{2+}$ to produce abundant $\mathrm{OH}$, which immediately attacks organic matters and oxidizes the unreacted $\mathrm{Fe}^{2+}$. As a result, at the beginning of the reaction, the degradation velocity of COD is very 
high. As the reaction continues, $\mathrm{H}_{2} \mathrm{O}_{2}$ and $\mathrm{Fe}^{2+}$ are gradually consumed. Although $\mathrm{Fe}^{3+}$ can still be reduced to $\mathrm{Fe}^{2+}$, this reduction reaction is carried out at a lower rate. In this process, $\mathrm{Fe}^{3+}$ might be hydrolyzed, which will reduce the degradation rate of organic matters. For these reasons, the best reaction time of pharmaceutical wastewater is determined as $30 \mathrm{~min}$ while that of papermaking wastewater as $60 \mathrm{~min}$.

\subsubsection{Reutilization experiment of pyrites cinder.}

The single factor experiment is conducted under the optimal condition, namely, dosage of $\mathrm{FeSO}_{4} \cdot 7 \mathrm{H}_{2} \mathrm{O}$ of $0.3 \mathrm{mmol}, 10 \mathrm{~g}$ pyrites cinder, $\left[\mathrm{H}_{2} \mathrm{O}_{2}\right]:\left[\mathrm{Fe}^{2+}\right]$ of $8: 1,30 \mathrm{~min}$ reaction in pharmaceutical wastewater and $60 \mathrm{~min}$ reaction in paper-making wastewater. After each experiment, the wastewater is discarded and the cinder saved to investigate the influence of times of pyrites cinder usage on the COD removal rate in the wastewater with the results shown in Fig. 5.

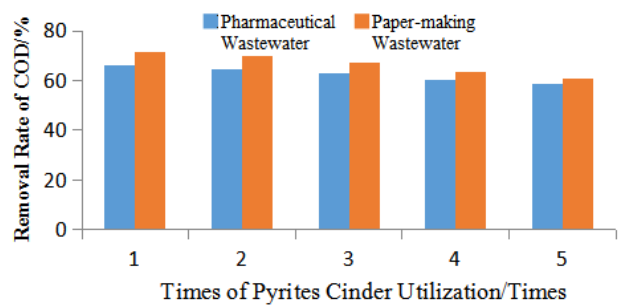

Fig. 5 The influence of the times of pyrites cinder utilization on COD removal rate

It can be seen from Fig. 5 that along with the increase of utilization times, the catalytic effect of cinder reduces but in an insignificant way. After five times, the COD removal rate in these two paper-making wastewater still remains at $60 \%$, a fact indicating that the various elements in the cinder are basically not consumed but catalyze $\mathrm{H}_{2} \mathrm{O}_{2}$ together with $\mathrm{Fe}^{2+}$. This expands the $\mathrm{pH}$ range of Fenton and reduces the dosage of $\mathrm{Fe}^{2+}$ and $\mathrm{H}_{2} \mathrm{O}_{2}$.

\section{Conclusions}

Through orthogonal test, the influence of each factor is presented in descending order as: pharmaceutical wastewater: $\mathrm{FeSO}_{4} \cdot 7 \mathrm{H}_{2} \mathrm{O}$ dosage $>\quad\left[\mathrm{H}_{2} \mathrm{O}_{2}\right]$ : $\left[\mathrm{Fe}^{2+}\right]>$ reaction time $>$ cinder dosage; paper-making wastewater: $\left[\mathrm{H}_{2} \mathrm{O}_{2}\right]:\left[\mathrm{Fe}^{2+}\right]>\mathrm{FeSO}_{4} \cdot 7 \mathrm{H}_{2} \mathrm{O}$ dosage $>$ cinder dosage $>$ reaction time. It shows that the utilization effect of cinder in pharmaceutical wastewater is less satisfactory than that in paper-making wastewater.

The optimal condition for the advanced treatment of pharmaceutical wastewater and paper-making wastewater by catalyzing $\mathrm{H}_{2} \mathrm{O}_{2}$ with cinder and $\mathrm{Fe}^{2+}$ is the dosage of pyrites cinder of $10 \mathrm{~g} \cdot \mathrm{L}^{-1}$, the dosage of $\mathrm{FeSO}_{4} \cdot 7 \mathrm{H}_{2} \mathrm{O}$ of $0.3 \mathrm{mmol} \cdot \mathrm{L}^{-1},\left[\mathrm{H}_{2} \mathrm{O}_{2}\right]:\left[\mathrm{Fe}^{2+}\right]$ of $8: 1$, the reaction time of pharmaceutical wastewater of $30 \mathrm{~min}$ and reaction time of paper-making wastewater of $60 \mathrm{~min}$. Under the optimal condition, the removal rate of COD in pharmaceutical wastetwater and paper-making wastewater can reach $65 \%$ and $72 \%$ respectively. This method does not require the regulation of the $\mathrm{pH}$ of inflow or high dosage of reagents, which testifies to the simple operation.

The cinder still possesses certain concerted catalysis capacity even after five times of reutilization with a COD removal rate in the two wastewater of more than $60 \%$.

\section{Acknowledgements}

Supported by Postdoctoral Science Foundation of Henan Province, China (NO.155889);

Supported by Programs for Science and Technology Development of Henan Province, China (NO.162102210084)

\section{References}

1. D. L. Zhang, Y.P. Huang, G.F. Luo, et al. Environmental Chemistry, 25 (2006).

2. L. P. Wang, H. Cai, Y.Z.Chen, et al. China Water and Wastewater, 26 (2010). .

3. X. S. Wang, D.H. Zhang, Y.F.Ren. Environmental Engineering, 17 (1999).

4. Tongji University. Fenton-like Oxidation of Refractory Organic Contaminants in Waste Water Using Pyrite Cinder at Neutral pH .P. China Patent: 101745197.2010-06-23.

5. D. L. Wu,D.Duan , L.M.Ma. CIESC Journal(China), 61 (2010).

6. Z. P. Xing Treatment of Antibiotic Fermentation Wastewater Using Combined CoagulationHydrolysis/Aerobic Moving Bed Biofilm ReactorFenton Process .D. (2008).

7. Y. Q. Li, Y.Ma , G.E.Qian, . Industrial Water Treatment, 29 (2008).

8. X. Zhang, H. L.Jiang, Industrial Water Treatment, 27 (2007).

9. L. H. Mo,K. F .Chen, Z. X.Chen, China Pulp \& Paper, 23(2004).

10. Sealey J, Ragauskas A J. Enzyme and Mierobial Technology, 23(1998).

11. D F Zeng, D Hu, J Cheng.Journal of Water Chemistry and Technology,34(2012).

12. State Environmental Protection Administration. Detection and Analysis Method of Water and Wastewater (4th EDITION). (2002).

13. K Namgoo,S L Dong ,Y Jeyong . Chemosphere,47(2002).

14. C. H. Chen, B. Xie,Y. Ren, et al. J.E.S, 21(2000) 